\title{
Plasma proteome changes linked to late phase response after inhaled allergen challenge in asthmatics
}

\author{
Maria Weitoft ${ }^{1 \dagger}{ }^{\dagger}$, Måns Kadefors $^{1 \dagger}$, Henning Stenberg ${ }^{2,3}$, Ellen Tufvesson ${ }^{2}$, Zuzana Diamant ${ }^{2,4,5}$, \\ Sara Rolandsson Enes ${ }^{1}$, Leif Bjermer², Oskar Rosmark ${ }^{1 *}$ (D) and Gunilla Westergren-Thorsson'
}

\begin{abstract}
Background: A subset of individuals with allergic asthma develops a late phase response (LPR) to inhaled allergens, which is characterized by a prolonged airway obstruction, airway inflammation and airway hyperresponsiveness. The aim of this study was to identify changes in the plasma proteome and circulating hematopoietic progenitor cells associated with the LPR following inhaled allergen challenge.

Methods: Serial plasma samples from asthmatics undergoing inhaled allergen challenge were analyzed by mass spectrometry and immunosorbent assays. Peripheral blood mononuclear cells were analyzed by flow cytometry. Mass spectrometry data were analyzed using a linear regression to model the relationship between airway obstruction during the LPR and plasma proteome changes. Data from immunosorbent assays were analyzed using linear mixed models.

Results: Out of 396 proteins quantified in plasma, 150 showed a statistically significant change $23 \mathrm{~h}$ post allergen challenge. Among the most upregulated proteins were three protease inhibitors: alpha-1-antitrypsin, alpha-1-antichymotrypsin and plasma serine protease inhibitor. Altered levels of 13 proteins were associated with the LPR, including increased factor XIII A and decreased von Willebrand factor. No relationship was found between the LPR and changes in the proportions of classical, intermediate, and non-classical monocytes.

Conclusions: Allergic reactions to inhaled allergens in asthmatic subjects were associated with changes in a large proportion of the measured plasma proteome, whereof protease inhibitors showed the largest changes, likely to influence the inflammatory response. Many of the proteins altered in relation to the LPR are associated with coagulation, highlighting potential mechanistic targets for future treatments of type-2 asthma.
\end{abstract}

Keywords: Airway inflammation, Allergic asthma, Coagulation, Mass spectrometry, Protease inhibition

\section{Background}

Asthma is a heterogeneous disease with a diverse immunopathology reflected in various clinical phenotypes or endotypes and affects approximately 300 million people

\footnotetext{
*Correspondence: oskar.rosmark@med.lu.se

${ }^{\dagger}$ Maria Weitoft and Måns Kadefors shared first authorship

${ }^{1}$ Division of Lung Biology, Department of Experimental Medical Science, Lund University, Lund, Sweden

Full list of author information is available at the end of the article
}

worldwide [1, 2]. There is a close association between allergy and asthma, and allergen-driven asthma is considered the most common phenotype of asthma in children and younger adults [3]. Allergen challenge of subjects with allergic asthma serves as a model to study several features of acute and chronic responses to inhaled allergens. Based on the drop in forced expiratory volume in one second $\left(\mathrm{FEV}_{1}\right)$, allergen-induced airway responses are generally defined as an early phase response (EPR), original author(s) and the source, provide a link to the Creative Commons licence, and indicate if changes were made. The images or other third party material in this article are included in the article's Creative Commons licence, unless indicated otherwise in a credit line to the material. If material is not included in the article's Creative Commons licence and your intended use is not permitted by statutory regulation or exceeds the permitted use, you will need to obtain permission directly from the copyright holder. To view a copy of this licence, visit http://creativecommons.org/licenses/by/4.0/. The Creative Commons Public Domain Dedication waiver (http://creativeco mmons.org/publicdomain/zero/1.0/) applies to the data made available in this article, unless otherwise stated in a credit line to the data. 
which can be followed by a late phase response (LPR), usually starting between 4 and $8 \mathrm{~h}$ post allergen challenge [4]. While the EPR is an IgE-mediated, mast cell-triggered phenomenon occurring within minutes of allergen exposure and lasting up to approximately $2-3 \mathrm{~h}$, the LPR is associated with the recruitment of several inflammatory leukocytes and the release of their inflammatory products. It can last for several hours to days and is associated with more chronic sequelae including airway hyperresponsiveness [5]. Approximately 50\% of subjects with allergic asthma develop a LPR, which affects small airways to a larger extent, indicative of a more extensive airway pathology [6]. Airway remodeling, such as subepithelial fibrosis, correlates with the number of circulating fibrocytes in asthma [7, 8]. Circulating fibrocytes have been described to derive from $\mathrm{CD} 34^{+}$hematopoietic pool of progenitors or/and from a subset of CD14 ${ }^{+}$ $\mathrm{CD} 16^{-}$group of monocytes $[9,10]$. This possible source of structural cells is recruited from the circulation into the tissue through the SDF-1/CXCR4 axis upon interaction with hyaluronan and associates with platelet activation and blood clotting [11-13].

The molecular mechanisms underlying the LPR, including the recruitment of hematopoietic progenitors, are still not fully clarified. In this study, we studied plasma samples and peripheral blood mononuclear cells (PBMCs) from subjects with an allergen induced EPR with varying degrees of LPR following an inhaled allergen challenge [6]. The aim was to investigate changes in proteome profile and hematopoietic progenitor cell recruitment related to the LPR, represented by the maximal decrease in $\mathrm{FEV}_{1} 4-8 \mathrm{~h}$ post allergen challenge (late $\mathrm{FEV}_{1}$ drop). Consequently, we observed distinguishing factors associated with a LPR suggestive of new mechanisms, which warrant further research that can contribute to the development of targeted treatment strategies.

\section{Materials and methods}

\section{Subjects and study design}

An overview of the study design is shown in Fig. 1. The material was collected from a larger trial focusing on lung physiology and biomarkers [6]. In total, 32 subjects with allergic asthma were included in the study (subject characteristics listed in Table 1, details in Additional file 1: Table S1 including subject allocation to the different analyses). All subjects were in overall good health with no respiratory infection within 3 weeks before screening, confirmed a clinically stable asthma. None of the subjects were smokers (within 1 year before screening or $>10$ pack-years) or had received treatment with leukotriene or muscarinic receptor antagonists, phosphodiesterase inhibitors, oral corticosteroids, biologicals (e.g., anti-IgE, anti-IL5) or allergen-specific immunotherapy within 6 months before screening. Approximately $50 \%$ of subjects were on a stable dose of ICS ( $\leq 400 \mu \mathrm{g}$ budesonide/day) for at least 3 months

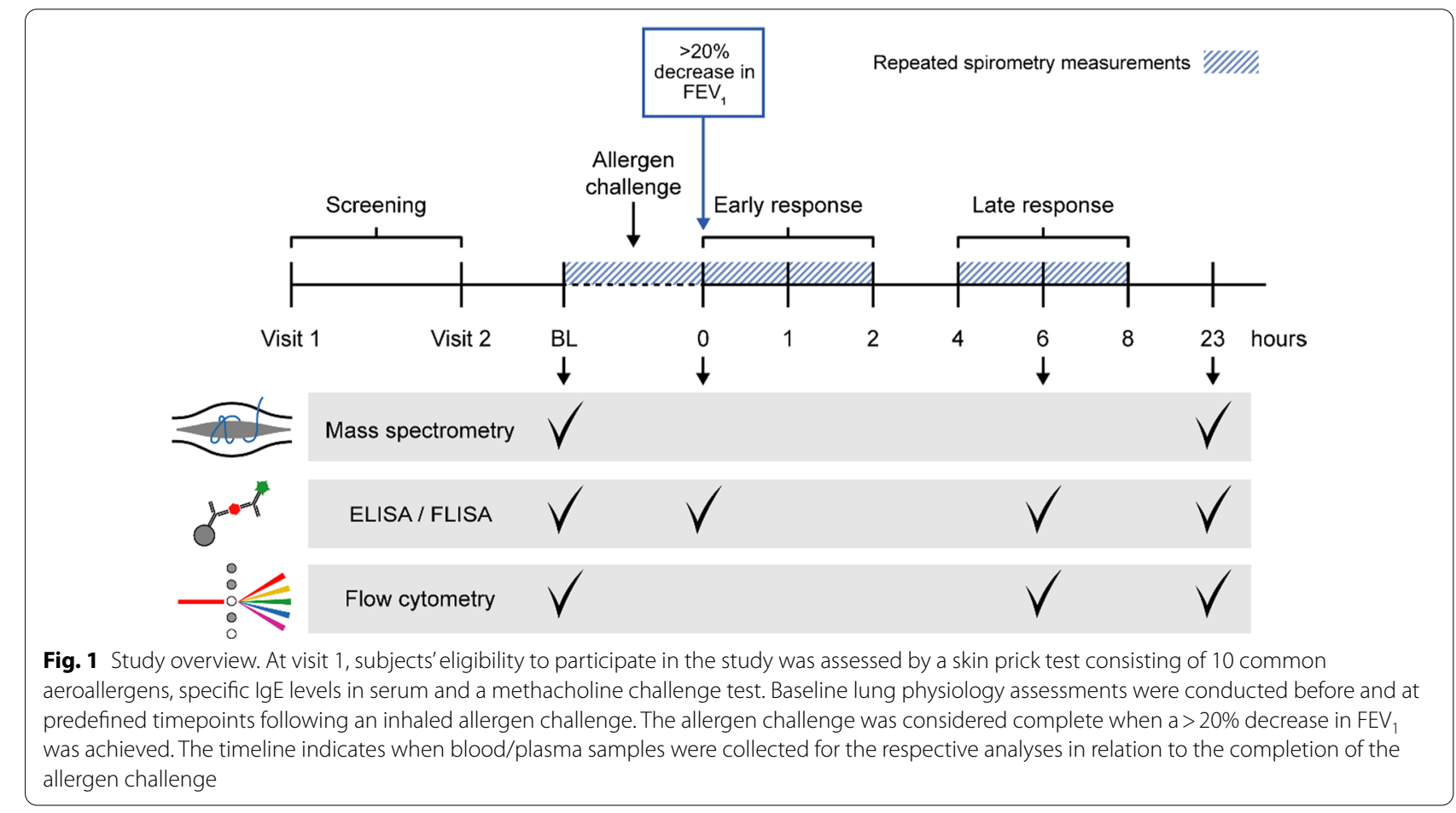


Table 1 Subject characteristics

\begin{tabular}{|c|c|c|c|}
\hline & All $(n=32)$ & $\begin{array}{l}\text { Single } \\
\text { responders } \\
(n=18)\end{array}$ & $\begin{array}{l}\text { Dual } \\
\text { responders } \\
(\mathrm{n}=14)\end{array}$ \\
\hline $\operatorname{Sex}(F / M)$ & $16 / 16$ & $9 / 9$ & $7 / 7$ \\
\hline Age (y) & $27(24-37)$ & $27(26-42)^{*}$ & $24(22-30)^{*}$ \\
\hline BMl & $24(22-26)$ & $23(22-26)$ & $24(23-26)$ \\
\hline Regular ICS use (n) & 15 & 6 & 9 \\
\hline FEV1 Baseline (\% predicted) & $96(90-104)$ & $95(88-103)$ & $95(92-105)$ \\
\hline Early drop in FEV1 (\%) & $23(21-25)$ & $22(21-25)$ & $23(21-25)$ \\
\hline $\begin{array}{l}\text { Max. drop in FEV1 after } \\
4-8 \mathrm{~h}(\%)\end{array}$ & $10(7-17)$ & $7(5-9)$ & $20(15-24)$ \\
\hline $\begin{array}{l}\text { Allergen used in challenge } \\
\text { (n) (Cat/Horse/HDM/ Birch/ } \\
\text { Grass) }\end{array}$ & $17 / 6 / 2 / 4 / 3$ & $10 / 4 / 1 / 2 / 1$ & $7 / 2 / 1 / 2 / 2$ \\
\hline \multicolumn{4}{|c|}{$\begin{array}{l}\text { Data presented as median (IQR). } \mathrm{BMI}=\text { body mass index, } \mathrm{FEV} 1=\text { forced } \\
\text { expiratory volume in } 1 \mathrm{~s}, \mathrm{ICS}=\text { inhaled glucocorticosteroid (maximal dose of } \\
400 \mu \mathrm{g} \text { Budesonide/day) }\end{array}$} \\
\hline \multicolumn{4}{|c|}{$\begin{array}{l}\text { Statistical differences between single and dual responders were analysed using } \\
\text { non-parametric Mann-Whitney, * denotes } p<0.05\end{array}$} \\
\hline
\end{tabular}

prior to the study, which remained unchanged throughout the study (Table 1). Short- and long-acting beta2agonists were withheld for $8 \mathrm{~h}$ and $48 \mathrm{~h}$, respectively, prior to any study-related procedures.

Subjects were screened on two separate screening visits (Fig. 1) with methacholine and mannitol challenge performed as previously described [6]. Eligible subjects underwent a standardized titrated inhaled allergen challenge with a sensitizing allergen (based on subject history and allergen testing), as previously described [6]. Flow volume spirometry was conducted with a Jaeger MasterScope (Erich Jaeger $\mathrm{GmbH}$ ), at baseline (BL) and predefined time points following allergen challenge, in accordance with European Respiratory Society (ERS)/American Thoracic Society (ATS) standards [14].

For allocation of subjects for flow cytometry and immunosorbent assays, subjects were designated as either single responders (SR) or dual responders (DR), where the latter had a decrease in $\mathrm{FEV}_{1}>12 \% 4-8 \mathrm{~h}$ post allergen challenge (Fig. 1). SR and DR differed in age and ICS use, but not in any other variable, including $\mathrm{BL} \mathrm{FEV}{ }_{1}$, duration of asthma, ACT-score, methacholine PD20, mannitol PD15, total IgE levels, serum specific IgE levels, SPT wheal diameter or number of sensitizations. Additional subject characteristics have previously been published [6]. Blood samples for analysis of plasma components (proteins and glycosaminoglycans) were collected in EDTA tubes before allergen challenge (BL), 0 and $0.5,1,2,6,8$ and $23 \mathrm{~h}$ after the allergen challenge [15]. Blood samples for preparation of PBMCs were collected in heparin tubes at $\mathrm{BL}$, as well as 6 and $23 \mathrm{~h}$ after allergen challenge.

\section{Liquid chromatography-mass spectrometry analysis of plasma samples}

Experimental details are provided in the supporting information. In brief, reduced and alkylated plasma protein samples were digested with Lys $\mathrm{C}$ followed by trypsin, desalted and spiked with retention time peptides before injection of $1 \mu \mathrm{g}$ peptide/sample. Analysis was performed on a QExactive HF-X (Thermo Fischer Scientific) mass spectrometer operated in data-independent acquisition (DIA) mode. DIA data were analyzed by using Spectronaut against a plasma spectral library provided by Wåhlén et al. (manuscript in preparation). An FDR of 0.01 using $Q$ value were employed for both precursor and protein identification. The data were exported from Spectronaut and downstream statistical analysis was performed in R (version 4.0.2). The mass spectrometry (MS) proteomics data have been deposited to the ProteomeXchange Consortium via the PRIDE [16] partner repository with the dataset identifier PXD027091.

\section{DIA data normalization and processing}

Proteins quantified in less than half of the samples at each timepoint and common contaminants were excluded from further analysis. Protein quantity values were normalized by dividing the value for each protein with the summed intensities for all quantified proteins in the respective sample, followed by $\log ^{2}$ transformation. Normalized data were analyzed using the DEqMS software package in $\mathrm{R}$ including timepoint (BL or $23 \mathrm{~h}$ ), sex, BMI and age as factors for a linear model [17]. Statistics for the differences between BL and $23 \mathrm{~h}$ were extracted. A separate model was fitted where the difference between $\mathrm{BL}$ and $23 \mathrm{~h}$ protein was analyzed against the same factors, but with late $\mathrm{FEV}_{1}$ drop in place of timepoint. Inclusion of ICS dose in the models had limited impact on the results and was left out to avoid overfitting.

\section{Functional enrichment analysis}

We used STRING [18] and Gene Ontology [19, 20] to perform a functional enrichment analysis for the significantly altered proteins after allergen challenge. Overrepresentation analysis of protein groups related to biological process terms was performed with the FDR set to $<5 \%$, using the Benjamani-Hochberg method. 


\section{Luminex assay for quantification of selected plasma proteins}

Five of the significantly altered proteins in the MS analysis were manually selected for luminex analysis, based on change between BL and $23 \mathrm{~h}$ for the entire study population, or late $\mathrm{FEV}_{1}$ drop. The selection was made based on conceived pathophysiological interest. Plasma samples were from timepoints BL, 0 min (EPR), $6 \mathrm{~h}$ (LPR), and $23 \mathrm{~h}$, from $10 \mathrm{SR}$ and $10 \mathrm{DR}$. Proteins were quantified according to the manufacturers' instructions on a Luminex MAGPIX instrument (Luminex Human Magnetic Assay, R\&D Systems).

\section{Hyaluronan and SDF-1 ELISA}

Total plasma hyaluronan $(n=18)$ and $\operatorname{SDF}-1 \quad(n=6)$ were quantified using two commercially available ELISA kits (R\&D Systems, Hyaluronan Quantikine ELISA Kit, DHYAL0, Human CXCL12/SDF-1 alpha Quantikine ELISA Kit, DSA00).

\section{Statistical analysis of FLISA and ELISA data}

We used R (version 4.0.2) and lme4 [21] to perform a linear mixed effects analysis of how protein quantification values from FLISA and ELISA measurements varied depending on time after allergen challenge and late $\mathrm{FEV}_{1}$ drop. One model was fitted for each protein and values from FLISA measurements were $\log ^{2}$ transformed before analysis. Age, BMI, use of ICS and sex were entered into the model as fixed effects, without interaction terms. Random effects consisted of random intercepts for subjects. No obvious deviation from normality or homoscedasticity were found by visual inspection of residual plots. p-values and confidence intervals from the lme4 models were obtained using the R package sjPlot [22] employing the Kenward-Roger approximation for the degrees of freedom. Plots were generated using GraphPad Prism version 8.3.0.

\section{Flow cytometric analysis}

Experimental details on PBMC isolation, flow cytometry staining and analysis are provided in the supporting information.

\section{Results}

\section{Plasma proteome changes persist $23 \mathrm{~h}$ after inhaled allergen challenge}

To identify plasma proteome alterations associated with allergic reaction, samples from $\mathrm{BL}$ and $23 \mathrm{~h}$ post allergen provocation were analyzed using label-free DIA-MS. A total of 396 plasma proteins were quantified, whereof 84 were immunoglobulin chains. When comparing plasma proteome profiles based on allergen provocation from BL and $23 \mathrm{~h}$ we identified 150 proteins that statistically significantly differed (adjusted p-value $<0.05)$, of which 15 proteins had a $>30 \%$ change from BL to $23 \mathrm{~h}$ (Fig. 2A, Additional file 1: Fig. S1). Among these 15 proteins, three protease inhibitors showed consistent and substantial increases $23 \mathrm{~h}$ postallergen challenge, i.e. alpha-1-antitrypsin, alpha-1-antichymotrypsin and plasma serine protease inhibitor (Fig. 2A). In contrast, SAFB-like transcription modulator, autotaxin, obscurin, serum amyloid P (SAP)-component and collagen alpha-1(I) chain were among the proteins showing significant decreases $23 \mathrm{~h}$ post-allergen challenge (Fig. 2A).

\section{Specific plasma proteome changes are associated with the LPR}

To find proteome alteration associated with the LPR, change in protein levels between BL and $23 \mathrm{~h}$ (delta values) were analyzed against late $\mathrm{FEV}_{1}$ drop (adjusted for sex, BMI and age), which identified 13 proteins that were significantly altered based on late $\mathrm{FEV}_{1}$ drop, and thus degree of LPR (Fig. 3A). The change in levels for FetuinA, coagulation factor XIII A chain, protein Z-dependent protease inhibitor and protein S100A9 all had a positive correlation with the size of the LPR. Among the proteins for which decreasing levels correlated with late $\mathrm{FEV}_{1}$ drop were four proteins linked to platelet activation and blood clot formation: von Willebrand factor, alpha1B-glycoprotein, platelet glycoprotein Ib alpha chain and coagulation factor XIII B chain (Fig. 3A, Additional file 1: Fig. S2).

\section{Functional enrichment analysis of significantly altered proteins according to MS-analysis}

To explore protein-protein interactions and to identify potentially enriched pathways following allergen challenge, we used String database and Gene Ontology to examine protein-protein interactions and to perform an enrichment analysis of proteins with significantly altered abundance after allergen provocation. There were five pathways associated with the altered protein profile after allergen challenge irrespective of late $\mathrm{FEV}_{1}$ drop. Significantly enriched pathways included the acute phase response, negative regulation of hydrolase activity, negative regulation of endopeptidase activity, negative regulation of protein metabolic process, and blood coagulation (Fig. 2B). Based on late $\mathrm{FEV}_{1}$ drop, there were 21 significantly enriched pathways, including several pathways involved in regulation of blood coagulation and fibrin clot formation as well as regulation of metabolic processes (Fig. 3B). 


\begin{tabular}{|c|c|c|c|c|c|}
\hline \multirow{2}{*}{ A } & Proteins & Quantified peptides & Adj. P-value & \multirow[t]{2}{*}{ Slope } & \\
\hline & Alpha-1-antitrypsin & 3 & $2,5 \times 10^{\wedge}-09$ & & 1,56 \\
\hline & Alpha-1-antichymotrypsin & 1 & $2,5 \times 10^{\wedge}-09$ & 个 & 2,29 \\
\hline & SAFB-like transcription modulator & & $2,3 \times 10^{\wedge}-07$ & $\downarrow$ & 0,11 \\
\hline & Thyroxine-binding globulin & & $2,6 \times 10^{\wedge}-05$ & 个 & 1,46 \\
\hline & Obscurin & & $2,1 \times 10^{\wedge}-04$ & $\downarrow$ & 0,5 \\
\hline & Serum amyloid P-component & & $4,3 \times 10^{\wedge}-04$ & $\downarrow$ & 0,63 \\
\hline & Plasma serine protease inhibitor & & $2,8 \times 10^{\wedge}-03$ & 个 & 1,52 \\
\hline & LINE-1 type transposase domain-containing protein 1 & & $3,6 \times 10^{\wedge}-03$ & $\uparrow$ & 1,5 \\
\hline & Immunoglobulin lambda variable 1-36 & & $5 \times 10^{\wedge}-03$ & 4 & 1,35 \\
\hline & Hemoglobin subunit alpha & & $5,8 \times 10^{\wedge}-03$ & 个 & 1,67 \\
\hline & Immunoglobulin kappa variable 2D-40 & & $1,2 \times 10^{\wedge}-02$ & 千 & 1,67 \\
\hline & Immunoglobulin lambda-like polypeptide 1 & & $2,2 \times 10^{\wedge}-02$ & 个 & 1,43 \\
\hline & Pregnancy-specific beta-1-glycoprotein 9 & & $2,7 \times 10^{\wedge}-02$ & 个 & 1,71 \\
\hline & Autotaxin & & $3,8 \times 10^{\wedge}-02$ & $\downarrow$ & 0,68 \\
\hline & Collagen alpha-1(I) chain & & $5 \times 10^{\wedge}-02$ & $\downarrow$ & 0,63 \\
\hline \multicolumn{6}{|c|}{ acute-phase response } \\
\hline \multirow{2}{*}{\multicolumn{6}{|c|}{$\begin{array}{r}\text { negative regulation of hydrolase activity } \\
\text { negative regulation of endopeptidase activity } \\
\text { negative regulation of protein metabolic process } \\
\text { blood coagulation }\end{array}$}} \\
\hline & & & & & \\
\hline \multicolumn{6}{|c|}{$\begin{array}{l}\text { Fig. } 2 \text { Plasma proteins altered } 23 \mathrm{~h} \text { post allergen challenge in subjects with asthma. } \mathbf{A} \text { Proteins with a statistically significant change from BL } \\
\text { to } 23 \mathrm{~h} \text { post allergen challenge that are altered }>30 \% \text { compared to BL levels, according to DEqMS analysis. B Gene ontology terms that are } \\
\text { significantly overrepresented }(p<0.05) \text { for the proteins in } \mathbf{A} \text {, terms are sorted by decreasing } p \text {-value, } x \text {-axis show the size of the enrichment effect } \\
\text { [Log } 10(\text { observed/expected)] }\end{array}$} \\
\hline
\end{tabular}

(See figure on next page.)

Fig. 3 Plasma proteins with a change from BL to $23 \mathrm{~h}$ post allergen challenge that are associated with the LPR, approximated by the maximal drop in FEV $14-8 \mathrm{~h}$ post allergen challenge. A Table of proteins with a statistically significant change from BL to $23 \mathrm{~h}$ post allergen challenge that correlate with the drop in FEV 1 during the LPR, according to DEqMS analysis. B Gene ontology terms that are significantly overrepresented $(p<0.05)$ for the proteins in $\mathbf{A}$, terms are sorted by increasing $p$-value, $x$-axis shows the size of the enrichment effect [Log10(observed/expected)]

Allergen induced changes in levels of proand anti-inflammatory proteins normalize within $24 \mathrm{~h}$ To further study the proteins identified in the MS analysis SAP, autotaxin, fetuin-A, VWF, and S100A9 in plasma samples were analyzed with Luminex from 10 SRs and 10 DRs, at time points BL, 0 (EPR), 6 (LPR) and $23 \mathrm{~h}$. Autotaxin was decreased by $8 \%$ compared to BL at $6 \mathrm{~h}$ post allergen challenge ( $95 \% \mathrm{CI}-4$ to $-11 \%)$, with a tendency towards a decrease also at $0 \mathrm{~min}$ and $23 \mathrm{~h}$ post-allergen challenge (Fig. 4A). Autotaxin was influenced by sex (45\% lower levels in males, 95\% CI - 17 to $-64 \%$ ), in accordance with published data [23]. Fetuin-A was increased by $10 \%$ at $0 \mathrm{~min}$ (95\% CI 3-19\%) followed by smaller nonsignificant increases at 6 and $23 \mathrm{~h}$ post allergen challenge (Fig. 4B). SAP was increased by $29 \%$ at $0 \mathrm{~min}$ (95\% CI 6-58\%) followed by a non-significant increase compared 


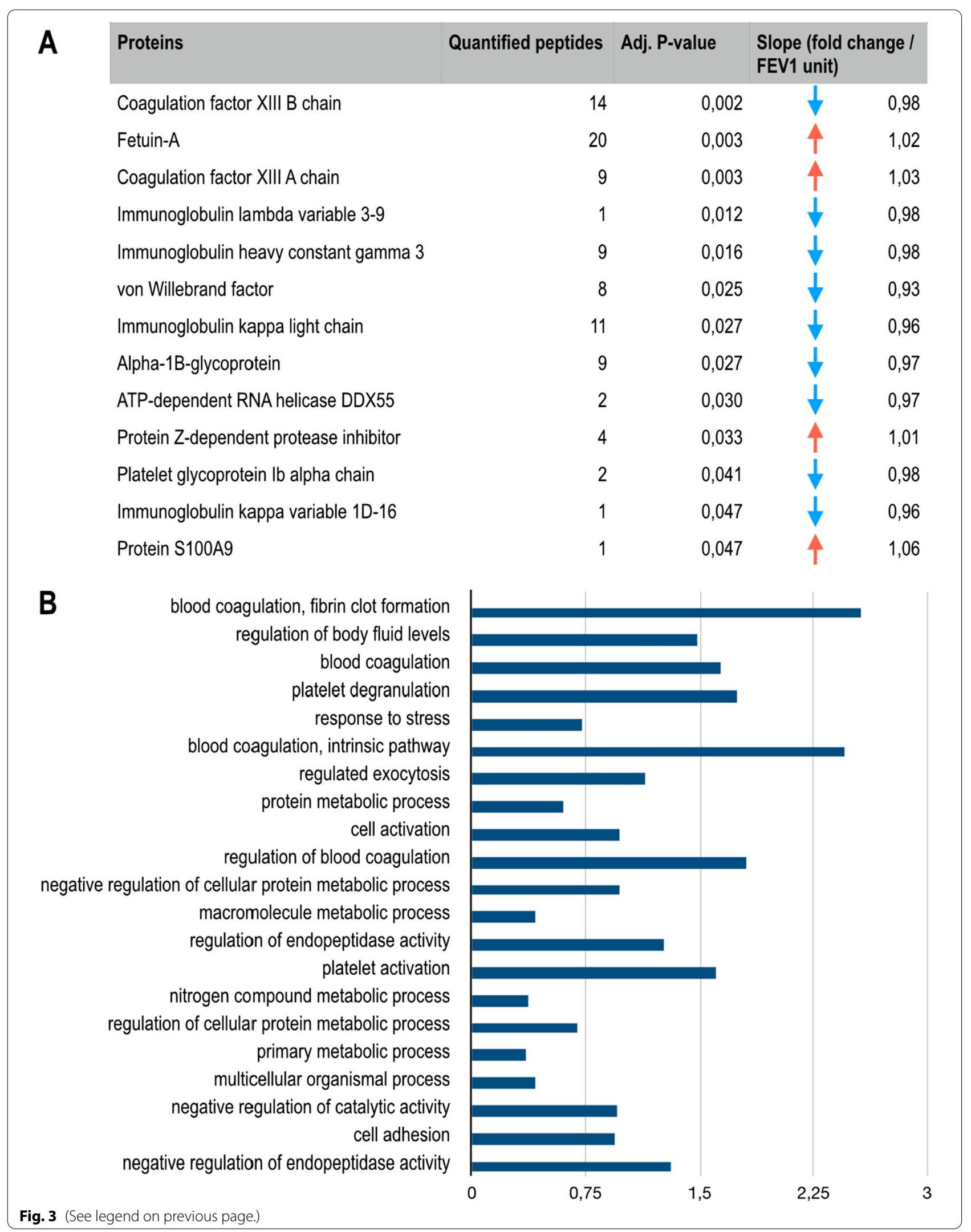



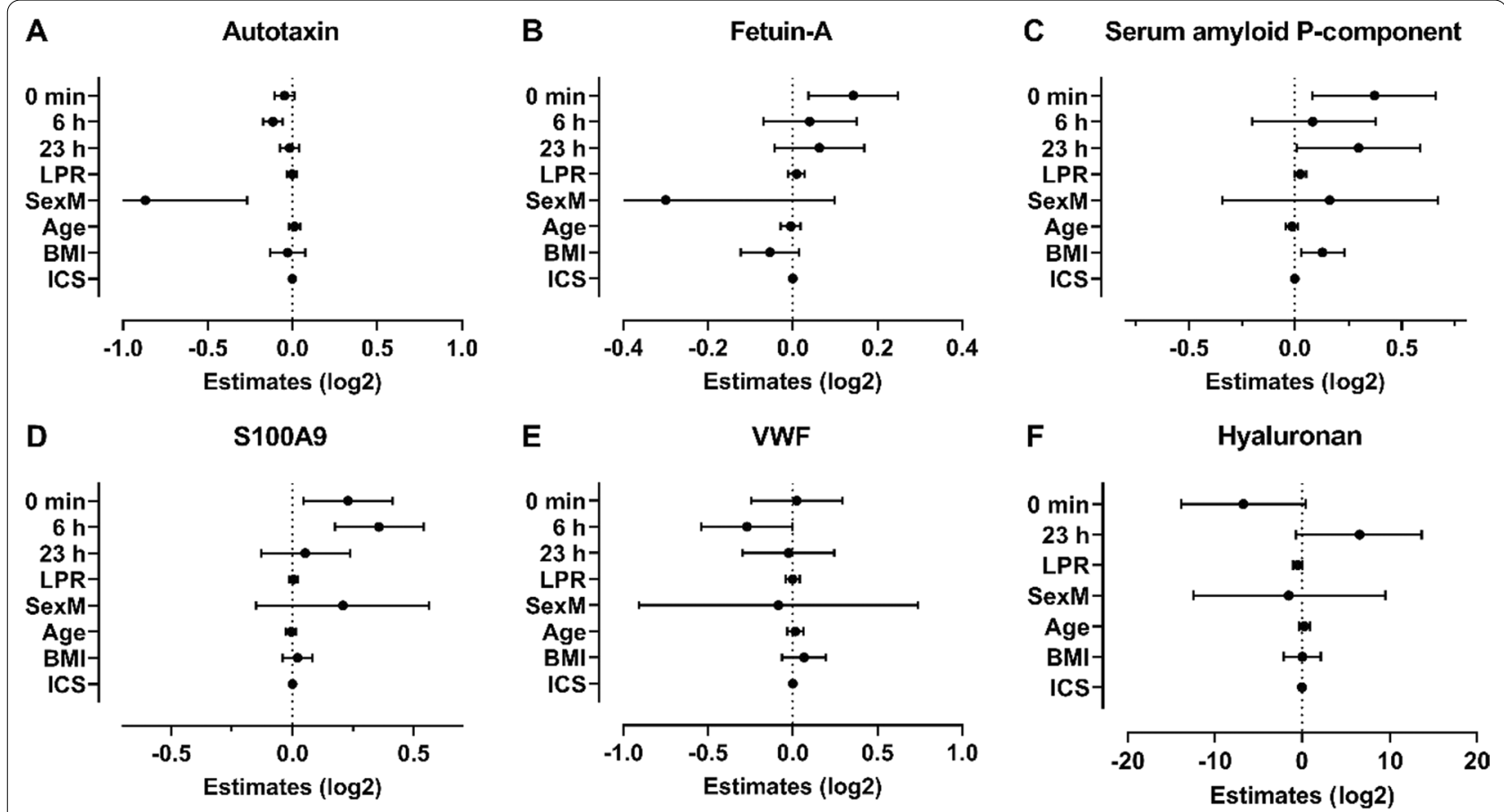

Fig. 4 Plasma composition changes following inhaled allergen challenge. Proteins in plasma samples were analyzed using a multiplex fluorophore linked immunosorbent assay (FLISA/Luminex) and hyaluronan were analyzed by ELISA. Statistical analysis was performed using linear mixed models. The time points $0 \mathrm{~min}, 6 \mathrm{~h}$ and $23 \mathrm{~h}$ are compared to BL values, LPR represents change per \% of late FEV 1 , SexM represents the effect of male sex where the point estimate for females constitutes the reference

to BL both at 6 and $23 \mathrm{~h}$ post-allergen challenge (Fig. $4 \mathrm{C}$ ). S100A9 was increased by $17 \%$ at 0 min $(95 \%$ CI $3-33 \%)$ and $28 \%$ at 6 h post allergen challenge (95\% CI $12-45 \%$, Fig. 4D). VWF had a tendency towards a decrease $6 \mathrm{~h}$ post provocation ( $95 \% \mathrm{CI}-0.02$ to $-31 \%$, Fig. $4 \mathrm{E})$. Collectively, four of the five analyzed proteins exhibited a change at least at one of the examined time points following allergen challenge. These four proteins have been suggested to be involved in the inflammatory reaction in asthma, fetuin considered mainly anti-inflammatory and the other three mainly pro-inflammatory [24-27]. None of the examined proteins had a significant association with the magnitude of the LPR or ICS use in this analysis.

\section{Temporal profiles of hyaluronan and SDF- 1 analyzed by ELISA}

Hyaluronan and SDF-1 are both known to play a role in the recruitment of inflammatory cells and therefore levels of hyaluronan and SDF-1 in plasma samples from SR and DR subjects were measured using ELISA. Plasma hyaluronan levels showed a non-significant decrease at 0 min compared to BL ( $95 \% \mathrm{CI}-47$ to $2 \%$ ), with a subsequent non-significant increase $23 \mathrm{~h}$ post allergen challenge (95\% CI -2 to $47 \%$ ), which could indicate a rapid turnover of the carbohydrate chain (Fig. 4F). There was no obvious association between hyaluronan levels in plasma and the magnitude of the LPR. The SDF- 1 analysis yielded results with large variance where no obvious pattern neither in relation to the temporal profile nor degree of LPR as assessed comparing SR and DR (Additional file 1: Fig. S3).

\section{No significant differences in proportions of classical, intermediate, and non-classical monocytes between single or dual responders}

To assess the effects of allergen challenge on the recruitment of circulating hematopoietic progenitors, blood samples were analyzed by flow cytometry. First, we identified circulating monocyte subsets and CD34+ hematopoietic progenitors at BL, and 6 and $23 \mathrm{~h}$ after allergen challenge from five SR and five DR. Representative data showing the flow cytometry gating strategy for monocyte subsets and CD34+hematopoietic progenitors are shown in (Fig. 5A).

Within the monocyte population $\left(\mathrm{CD} 45^{+} / \mathrm{CD}^{-} /\right.$ $\left.\mathrm{CD} 294^{-} / \mathrm{CD} 20^{-} / \mathrm{CD} 19^{-} / \mathrm{CD} 14^{+} / \mathrm{CD} 16^{+}\right)$we quantified classical (CD14 $\left.4^{\text {bright }} / \mathrm{CD} 16^{-}\right)$, intermediate $\left(\mathrm{CD} 14^{\text {bright }} / \mathrm{CD} 16^{+}\right)$and non-classical $\left(\mathrm{CD} 14^{-/ \mathrm{dim}} /\right.$ $\mathrm{CD} 16^{+}$) monocyte subsets. There was no significant difference in monocyte subset numbers when 


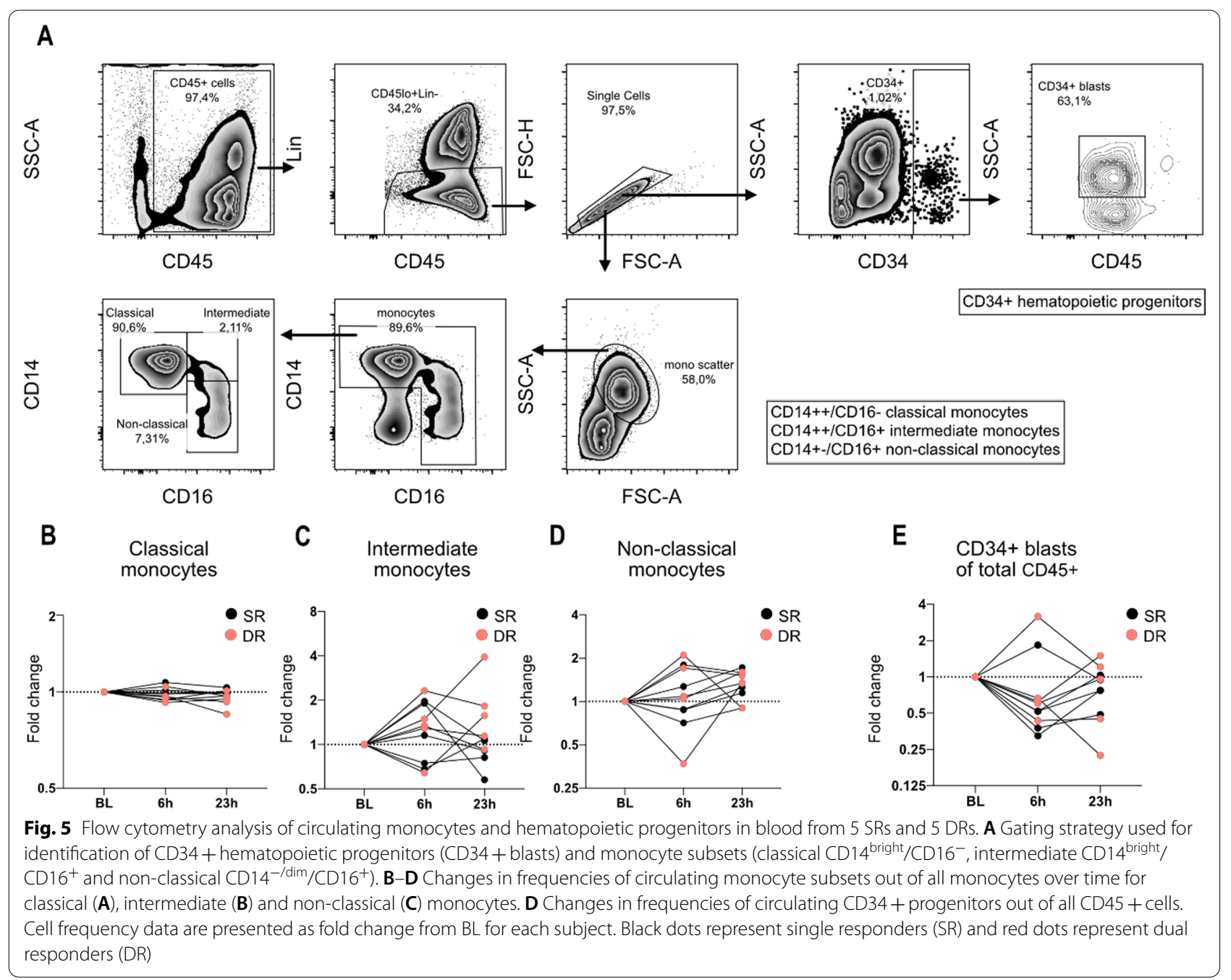

comparing time points or SR versus DR (Fig. 5B-D). The proportions of the subtypes; classical (89.7\%), intermediate (3.30\%) and non-classical (6.84\%) monocytes were similar to numbers reported by Sampath et al. [28]. We also examined the expression of CXC chemokine receptor 4 (CXCR4) on monocyte subsets, a receptor that is involved in the recruitment of hematopoietic progenitors $[29,30]$. CXCR4 expression was 7.14 times higher in classical monocytes (median $\Delta$ MFI 1400) compared to non-classical monocytes (median $\triangle$ MFI 196). We could not detect any difference in CXCR4 expression between time points or between SR and DR (data not shown). Quantification of circulating CD34 + hematopoietic progenitors (CD34 $4^{\text {bright }} / C D 45^{\text {dim }}$ ) showed a non-significant decrease in frequency during the LPR (Fig. 5A and E).

\section{Discussion}

In this study plasma proteomics were applied to investigate pathways underlying the pathology of the LPR. In previous studies, including from our group, LPR has been shown to be associated with prolonged increases in clinical signs and symptoms, airway inflammation, airway hyperresponsiveness, small airways dysfunction and structural changes $[4,6,31-34]$. Proteomics data were analyzed by fitting a linear model, which identified 13 proteins linked to the development of a LPR, in addition, 150 proteins were significantly altered in abundance $23 \mathrm{~h}$ after allergen challenge irrespective of the LPR.

Pathway analysis of the proteins most affected by allergen challenge i.e., $>30 \%$ change from $\mathrm{BL}$ values, showed enrichment for acute phase response, blood coagulation and protease inhibition. Three protease inhibitors were among those showing the largest change, i.e., alpha-1-antitrypsin, alpha-1-antichymotrypsin and plasma serine protease inhibitor, all showing a $>50 \%$ increase from $\mathrm{BL}$, 
possibly reflecting an active regulation of inflammation induced protease activity. Alpha-1-antitrypsin, alpha1-antichymotrypsin and the downregulated protein SAP are all significantly altered acute phase proteins [35]. SAP belongs to the pentraxin family of proteins together with the widely used clinical marker of inflammation, C-reactive protein (CRP); the latter not showing a significant change in our MS-data. SAP has been shown to inhibit neutrophil adhesion to extracellular matrix, differentiation of hematopoietic myeloid progenitors into fibrocytes and to promote the formation of immune-regulatory macrophages [36, 37]. In the context of a response to inhaled allergen, SAP may have a protective role by driving monocyte differentiation towards the anti-inflammatory and anti-fibrotic M2c phenotype [38, 39].

Autotaxin is a secreted enzyme that produces most of the extracellular lipid mediator lysophosphatidic acid (LPA), that promote chemotaxis of Th2 cells and IL-13 expression [40]. A previous study showed increased sputum levels of autotaxin in allergic asthmatics following a segmental allergen challenge [24]. We found decreased plasma levels of autotaxin, a discrepancy possibly explained by a negative feedback mechanism, where high autotaxin activity in the lung could inhibit systemic expression of autotaxin measured in plasma via LPA, or the related lipid product sphingosine 1-phosphate [41].

The LPR associated proteins showed enrichment for biological processes related to hemostasis, which agrees with existing literature linking coagulation factors in sputum and plasma from subjects with asthma with an ongoing inflammatory process $[42,43]$. Two of these proteins, glycoprotein Ib alpha chain and VWF, work in concert to promote platelet adhesion and activation, the latter has also been found to be an important pro-inflammatory mediator involved in leukocyte extravasation [44]. Both proteins showed an inverse correlation to the late $\mathrm{FEV}_{1}$ drop in. Plasma VWF levels have been proposed to correlate to systemic inflammation [45].

Coagulation factor XIII is a transglutaminase known to stabilize fibrin clots as the final enzyme in the coagulation cascade [46]. Our data showed a positive correlation between the degree of LPR and levels of the catalytically active A subunit of coagulation factor XIII, and a negative correlation between LPR and the B subunit that serves a carrier/inhibitory role in the circulating pro-transglutaminase. A previous study has shown increased expression of coagulation factor XIII A in bronchoalveolar lavage after segmental allergen challenge and in induced sputum from patients with allergic asthma, with an association to type 2 inflammation and airway obstruction [48]. The functional role of coagulation factor XIII A is complex, as it has both intracellular- and extracellular functions beyond its role in coagulation e.g., serving to cross-link extracellular matrix proteins [46].

Our finding of a positive correlation between LPR and levels of protein S100A9 fits well with increased inflammation. S100A9 is constitutively expressed in immune cells, such as monocytes and neutrophils, and is released in response to environmental triggers and cellular damage [27]. A similar positive correlation was also found for fetuin-A, which has a dual role as a both positive and negative acute phase protein, depending on the mode of inflammation. High serum levels of sialylated fetuin-A have been shown to be predictive of clinical responsiveness to grass pollen immunotherapy $[25,49,50]$.

Hyaluronan fragments have previously been shown to enhance SDF-1 mediated migration of bone marrow derived CD34+ progenitor cells [11]. In our study, we were not able to detect any specific pattern regarding SDF-1 levels post allergen challenge, given the large intersubject variation and the limited number of subjects in the analysis. Hyaluronan showed a statistically non-significant decrease during the EPR. Despite no apparent effect on SDF-1, we saw a non-significant trend towards a decrease in circulating $\mathrm{CD} 34+$ progenitors during the LPR, which connects to a study by Schmidt et al., where an increase in fibrocytes was shown in the bronchial submucosa already $4 \mathrm{~h}$ after allergen exposure [51].

Finally, an obvious limitation to this study is the limited number of subjects, which limit statistical power. However, to lower the impact of inter-subject variability, subjects served as their own controls (BL values) and multilevel models was used to simultaneously analyze all proteins, which should result in an efficient effect estimation and better control of the so-called type I error [52]. A higher proportion of DR than SR used ICS, although, according to our statistical models, this was not associated with any significant effect on protein levels.

\section{Conclusion}

This explorative study on changes in the plasma proteome associated with EPR and LPR following inhaled allergen challenge may serve as a basis for finding new druggable asthma mechanisms and open new avenues for patient stratification, facilitating targeted therapies. Protease inhibitors are upregulated post allergen challenge, potentially mitigating the effect of inflammation-related proteases. We found distinguishing plasma proteome changes in subjects experiencing a pronounced late phase response following allergen exposure. Several of these proteins are linked to coagulation, and further studies on the role of coagulation factors in allergic inflammation are warranted. 


\section{Abbreviations}

BL: Baseline; CD: Cluster of differentiation; CXCR4: C-X-C motif chemokine receptor 4; DR: Dual responder; ELISA: Enzyme-linked immunosorbent assay; EPR: Early phase response; FEV1: Forced expiratory volume in one second; FLISA: Fluorescence-linked immunosorbent assay; FSC: Forward scatter; MFI: Median fluorescence intensity; ICS: Inhaled corticosteroids; LPR: Late phase response; MS: Mass spectrometry; PBMC: Peripheral blood mononuclear cell; SDF-1: Stromal cell-derived factor 1; SR: Single responder; SSC: Side scatter.

\section{Supplementary Information}

The online version contains supplementary material available at https://doi. org/10.1186/s12931-022-01968-0.

Additional file 1. Supporting information.

\section{Acknowledgements}

The authors would like to thank Marie Wildt for skillful technical assistance with the Luminex assay, Charlotte Welinder and Hong Yan at the BioMS facility in Lund University for the LC-MS analysis and the Unit of Lung and Allergy research for valuable assistance during patient testing.

\section{Authors' contributions}

MW: Investigation, Visualization, Writing —original draft, Writing-review \& editing. MK: Formal Analysis, Investigation, Visualization, Writing_original draft. HS: Investigation, Resources, Writing — review \& editing. ET: Data curation, Investigation, Resources, Writing - review \& editing. ZD: Conceptualization, Writing — review \& editing. SRE: Supervision, Writing — review \& editing. LB: Conceptualization, Funding acquisition, Resources, Writing-review \& editing. OR: Formal Analysis, Visualization, Writing —original draft, Writing — review \& editing. GWT: Conceptualization, Funding acquisition, Supervision, Writing - review \& editing. All authors read and approved the final manuscript.

\section{Funding}

Open access funding provided by Lund University. This work was funded by Swedish Research Council in Medicine and Health (2020-01375), the Swedish Heart-Lung Foundation (20180171, 20200651), the Swedish Asthma and Allergy Association, the Royal Physiographical Society in Lund, the Medical Faculty of Lund University. The Åke and Inger Bergkvist, Evy and Gunnar Sandberg, Greta and John Kock, Alfred Österlund, Crafoord, Mats Kleberg and Consul Thure Bergh foundations. ALF Grants Region Skåne and the Swedish Foundation for Strategic Research.

\section{Availability of data and materials}

The mass spectrometry (MS) proteomics datasets generated and analysed during the current study are available in the ProteomeXchange Consortium via the PRIDE [16] partner repository with the dataset identifier PXD027091.

\section{Declarations}

\section{Ethical approval and consent to participate}

The study was approved by the Regional Ethical Review Board in Lund, Sweden (2012/800). All subjects provided written informed consent before screening.

\section{Consent for publication}

Not applicable.

\section{Competing interests}

ZD acted as Research Director at QPS-NL, an institution which received research support from several bio-pharmaceutical companies. Furthermore, $Z D$ received honoraria or speaker fees serving on advisory boards or as a consultant from: ALK, AstraZeneca, Antabio, Boehringer Ingelheim, GlaxoSmithKline, HAL Allergy, Merck Sharp \& Dohme, Sanofi-Genzyme-Regeneron, all outside the scope of the submitted work. The other authors declare that they have no competing interests.

\section{Author details}

${ }^{1}$ Division of Lung Biology, Department of Experimental Medical Science, Lund University, Lund, Sweden. '2Division of Respiratory Medicine and Allergology, Department of Clinical Sciences Lund, Lund University, Lund, Sweden. ${ }^{3}$ Center for Primary Health Care Research, Department of Clinical Sciences Malmö, Lund University, Malmö, Sweden. ${ }^{4}$ Department of Microbiology Immunology and Transplantation, KU Leuven, Catholic University of Leuven, Leuven, Belgium. ${ }^{5}$ Department of Clin Pharm and Pharmacol, University of Groningen, Univ Med Ctr Groningen, Groningen, Netherlands.

Received: 3 September 2021 Accepted: 14 February 2022

Published online: 05 March 2022

\section{References}

1. Global Initiative for Asthma. Global Initiative for Asthma. Strategy for Asthma Management and Prevention, 2020. Available from 2020. www. ginasthma.org. Accessed October 15, 2020.

2. Wenzel SE. Asthma phenotypes: the evolution from clinical to molecular approaches. Nat Med. 2012;18(5):716-25. https://doi.org/10.1038/nm. 2678.

3. Cockcroft DW. Allergen-induced asthma. Vol 21. Hindawi Limited; 2014.

4. Diamant Z, Gauvreau GM, Cockcroft DW, et al. Inhaled allergen bronchoprovocation tests. J Allergy Clin Immunol. 2013. https://doi.org/10. 1016/j.jaci.2013.08.023.

5. Murdoch JR, Lloyd CM. Chronic inflammation and asthma. Mutat Res Fundam Mol Mech Mutagen. 2010;690(1-2):24-39. https://doi.org/10. 1016/j.mrfmmm.2009.09.005.

6. Stenberg H, Diamant Z, Ankerst J, Bjermer L, Tufvesson E. Small airway involvement in the late allergic response in asthma. Clin Exp Allergy. 2017;47(12):1555-65. https://doi.org/10.1111/cea.13036.

7. Bergeron C, Tulic MK, Hamid Q. Airway remodelling in asthma: from benchside to clinical practice. Can Respir J. 2010. https://doi.org/10.1155/ 2010/318029.

8. Nihlberg K, Larsen K, Hultgårdh-Nilsson A, Malmström A, Bjermer L, Westergren-Thorsson G. Tissue fibrocytes in patients with mild asthma: a possible link to thickness of reticular basement membrane? Respir Res. 2006. https://doi.org/10.1186/1465-9921-7-50.

9. Fischer KD, Agrawal DK. Hematopoietic stem and progenitor cells in inflammation and allergy. Front Immunol. 2013. https://doi.org/10.3389/ fimmu.2013.00428.

10. Tacke F, Randolph GJ. Migratory fate and differentiation of blood monocyte subsets. Immunobiology. 2006;211(6-8):609-18. https://doi.org/10. 1016/j.imbio.2006.05.025.

11. Sbaa-Ketata E, Courel M-N, Delpech B, Vannier J-P. Hyaluronan-derived oligosaccharides enhance SDF-1-dependent chemotactic effect on peripheral blood hematopoietic CD34+ cells. Stem Cells. 2002;20(6):5857. https://doi.org/10.1634/stemcells.20-6-585.

12. Suess PM, Chinea LE, Pilling D, Gomer RH. Extracellular polyphosphate promotes macrophage and fibrocyte differentiation, inhibits leukocyte proliferation, and acts as a chemotactic agent for neutrophils. J Immunol. 2019;203(2):493-9. https://doi.org/10.4049/jimmunol.1801559.

13. White MJV, Galvis-Carvajal E, Gomer RH. A brief exposure to tryptase or thrombin potentiates fibrocyte differentiation in the presence of serum or serum amyloid P. J Immunol. 2015;194(1):142-50. https://doi.org/10. 4049/jimmunol.1401777.

14. Graham BL, Steenbruggen I, Barjaktarevic IZ, et al. Standardization of spirometry 2019 update an official American Thoracic Society and European Respiratory Society technical statement. Am J Respir Crit Care Med. 2019;200(8):E70-88. https://doi.org/10.1164/rccm.201908-1590ST.

15. Stenberg H, Wadelius E, Moitra S, et al. Club cell protein (CC16) in plasma, bronchial brushes, BAL and urine following an inhaled allergen challenge in allergic asthmatics. Biomarkers. 2018;23(1):51-60. https://doi.org/10. 1080/1354750X.2017.1375559.

16. Perez-Riverol Y, Csordas A, Bai J, et al. The PRIDE database and related tools and resources in 2019: improving support for quantification data. Nucleic Acids Res. 2019;47(D1):D442-50. https://doi.org/10.1093/nar/ gky1106. 
17. Zhu Y, Orre LM, Tran $Y Z$, et al. DEqMS: a method for accurate variance estimation in differential protein expression analysis. Mol Cell Proteomics. 2020;19:1047-57. https://doi.org/10.1074/mcp.TIR119.001646.

18. Szklarczyk D, Franceschini A, Wyder S, et al. STRING v10: protein-protein interaction networks, integrated over the tree of life. Nucleic Acids Res. 2015;43(D1):D447-52. https://doi.org/10.1093/nar/gku1003.

19. Ashburner M, Ball CA, Blake JA, et al. Gene ontology: tool for the unification of biology. Nat Genet. 2000;25(1):25-9. https://doi.org/10.1038/ 75556.

20. Carbon S, Douglass E, Good BM, et al. The gene ontology resource: enriching a GOld mine. Nucleic Acids Res. 2021;49(D1):D325-34. https:// doi.org/10.1093/nar/gkaa1113.

21. Bates D, Mächler M, Bolker BM, Walker SC. Fitting linear mixed-effects models using Ime4. J Stat Softw. 2015;67(1):1-48. https://doi.org/10. 18637/jss.v067.i01.

22. Daniel Lüdecke. sjPlot: Data Visualization for Statistics in Social Science. 2020. https://cran.r-project.org/package =sjPlot.

23. Nakamura K, Igarashi K, Ide K, et al. Validation of an autotaxin enzyme immunoassay in human serum samples and its application to hypoalbuminemia differentiation. Clin Chim Acta. 2008;388(1-2):51-8. https://doi. org/10.1016/j.cca.2007.10.005.

24. Park GY, Lee YG, Berdyshev E, et al. Autotaxin production of lysophosphatidic acid mediates allergic asthmatic inflammation. Am J Respir Crit Care Med. 2013;188(8):928-40. https://doi.org/10.1164/rccm.201306-10140C.

25. Wang $H$, Sama AE. Anti-inflammatory role of fetuin-A in injury and infection. Curr Mol Med. 2012;12(5):625-33. https://doi.org/10.2174/15665 2412800620039.

26. Du Clos TW. Pentraxins: structure, function, and role in inflammation. ISRN Inflamm. 2013;2013:1-22. https://doi.org/10.1155/2013/379040.

27. Wang S, Song R, Wang Z, Jing Z, Wang S, Ma J. S100A8/A9 in inflammation. Front Immunol. 2018;9:1298. https://doi.org/10.3389/fimmu.2018. 01298.

28. Sampath P, Moideen K, Ranganathan UD, Bethunaickan R. Monocyte subsets: phenotypes and function in tuberculosis infection. Front Immunol. 2018;9:1726. https://doi.org/10.3389/fimmu.2018.01726.

29. Zou YR, Kottman AH, Kuroda M, Taniuchi I, Littman DR. Function of the chemokine receptor CXCR4 in heaematopolesis and in cerebellar development. Nature. 1998;393(6685):595-9. https://doi.org/10.1038/31269.

30. Mazo IB, Massberg S, von Andrian UH. Hematopoietic stem and progenitor cell trafficking. Trends Immunol. 2011;32(10):493-503. https://doi.org/ 10.1016/j.it.2011.06.011.

31. Kariyawasam HH, Aizen M, Barkans J, Robinson DS, Kay AB. Remodeling and airway hyperresponsiveness but not cellular inflammation persist after allergen challenge in asthma. Am J Respir Crit Care Med. 2007;175(9):896-904. https://doi.org/10.1164/rccm.200609-12600C.

32. $\mathrm{Gm} \mathrm{G}, \mathrm{Rm}$ W, Pm O. Kinetics of allergen-induced airway eosinophilic cytokine production and airway inflammation. Am J Respir Crit Care Med. 1999;160(2):640-7. https://doi.org/10.1164/AJRCCM.160.2.9809130.

33. Zuiker RGJA, Ruddy MK, Morelli N, et al. Kinetics of TH2 biomarkers in sputum of asthmatics following inhaled allergen. Eur Clin Respir J. 2015:2(1):28319. https://doi.org/10.3402/ECRJ.V2.28319.

34. Zuiker RGJA, Tribouley C, Diamant Z, et al. Sputum RNA signature in allergic asthmatics following allergen bronchoprovocation test. Eur Clin Respir J. 2016;3(1):31324. https://doi.org/10.3402/ECRJ.V3.31324.

35. Jain S, Gautam V, Naseem S. Acute-phase proteins: As diagnostic tool. J Pharm Bioallied Sci. 2011;3(1):118-27. https://doi.org/10.4103/0975-7406. 76489.

36. Maharjan AS, Roife D, Brazill D, Gomer RH. Serum amyloid P inhibits granulocyte adhesion. Fibrogenes Tissue Repair. 2013;6(1):2. https://doi. org/10.1186/1755-1536-6-2

37. Pilling D, Galvis-Carvajal E, Karhadkar TR, Cox N, Gomer RH. Monocyte differentiation and macrophage priming are regulated differentially by pentraxins and their ligands. BMC Immunol. 2017. https://doi.org/10. 1186/s12865-017-0214-z.

38. Lu J, Marnell LL, Marjon KD, Mold C, Du Clos TW, Sun PD. Structural recognition and functional activation of FcyR by innate pentraxins. Nature. 2008;456(7224):989-92. https://doi.org/10.1038/nature07468.

39. Castaño AP, Lin SL, Surowy T, et al. Serum amyloid P inhibits fibrosis through FcyR-dependent monocyte-macrophage regulation in vivo. Sci Transl Med. 2009;1(5):5-13. https://doi.org/10.1126/scitranslmed.30001 11.
40. Perrakis A, Moolenaar WH. Thematic review series: lysophospholipids and their receptors: autotaxin: structure-function and signaling. J Lipid Res. 2014;55(6):1010-8. https://doi.org/10.1194/jlr.R046391.

41. Benesch MGK, Zhao YY, Curtis JM, McMullen TPW, Brindley DN. Regulation of autotaxin expression and secretion by lysophosphatidate and sphingosine 1-phosphate. J Lipid Res. 2015;56(6):1134-44. https://doi. org/10.1194/jlr.M057661.

42. O'Brien M. The reciprocal relationship between inflammation and coagulation. Top Companion Anim Med. 2012;27(2):46-52. https://doi.org/10. 1053/j.tcam.2012.06.003.

43. Kowal K, Pampuch A, Kowal-Bielecka O, DuBuske LM, Bodzenta-Łukaszyk A. Platelet activation in allergic asthma patients during allergen challenge with Dermatophagoides pteronyssinus. Clin Exp Allergy. 2006;36(4):42632. https://doi.org/10.1111/j.1365-2222.2006.02446.x.

44. Petri B, Broermann A, Li H, et al. Von Willebrand factor promotes leukocyte extravasation. Blood. 2010;116(22):4712-9. https://doi.org/10.1182/ blood-2010-03-276311.

45. Kawecki C, Lenting PJ, Denis CV. von Willebrand factor and inflammation. J Thromb Haemost. 2017;15(7):1285-94. https://doi.org/10.1111/jth. 13696.

46. Muszbek L, Bereczky Z, Bagoly Z, Komáromi I, Katona É. Factor XIII: a coagulation factor with multiple plasmatic and cellular functions. Physiol Rev. 2011;91(3):931-72. https://doi.org/10.1152/physrev.00016.2010.

47. Fukuda T, Mochida S, Fukushima Y, Makino S. Detection of allergeninduced genes in peripheral blood mononuclear cells of patients with allergic asthma using subtractive hybridization. J Allergy Clin Immunol. 1995:96(6 SUPPL.):1076-82. https://doi.org/10.1016/S0091-6749(95) 70193-1.

48. Esnault S, Kelly EA, Sorkness RL, Evans MD, Busse WW, Jarjour NN. Airway factor XIII associates with type 2 inflammation and airway obstruction in asthmatic patients. J Allergy Clin Immunol. 2016;137(3):767-773.e6. https://doi.org/10.1016/j.jaci.2015.05.053.

49. Lebreton JP, Joisel F, Raoult JP, Lannuzel B, Rogez JP, Humbert G. Serum concentration of human alpha2 HS glycoprotein during the inflammatory process. Evidence that alpha2 HS glycoprotein is a negative acutephase reactant. J Clin Invest. 1979;64(4):1118-29. https://doi.org/10.1172/ JCl109551.

50. Caillot N, Bouley J, Jain K, et al. Sialylated Fetuin-A as a candidate predictive biomarker for successful grass pollen allergen immunotherapy. J Allergy Clin Immunol. 2017;140(3):759-770.e13. https://doi.org/10.1016/j. jaci.2016.10.036.

51. Schmidt M, Sun G, Stacey MA, Mori L, Mattoli S. Identification of circulating fibrocytes as precursors of bronchial myofibroblasts in asthma. J Immunol. 2003;171(1):380-9. https://doi.org/10.4049/jimmunol.171.1. 380.

52. Ji H, Liu XS. Analyzing 'omics data using hierarchical models. Nature Biotechnol. 2010;28:337-40. https://doi.org/10.1038/nbt.1619.

\section{Publisher's Note}

Springer Nature remains neutral with regard to jurisdictional claims in published maps and institutional affiliations.

Ready to submit your research? Choose BMC and benefit from:

- fast, convenient online submission

- thorough peer review by experienced researchers in your field

- rapid publication on acceptance

- support for research data, including large and complex data types

- gold Open Access which fosters wider collaboration and increased citations

- maximum visibility for your research: over 100M website views per year

At BMC, research is always in progress.

Learn more biomedcentral.com/submissions 